\title{
PROBLEMATIKA GURU DALAM MENINGKATKAN AKTIVITAS SISWA DI KELAS PADA PEMBELAJARAN MATEMATIKA
}

\author{
${ }^{1}$ Atik Ilaina Sanjaya, ${ }^{2}$ Siti Rika Rizqi Pratama \\ ${ }^{1}$ IAIN Jember, J1.Mataram No.1 Mangli, (0331)487550 \\ ${ }^{2}$ IAIN Jember, J1.Mataram No.1 Mangli, (0331)487550 \\ e-mail: ${ }^{1}$ atik.ilaina26@gmail.com, ${ }^{2}$ pratamarika06@gmail.com
}

\begin{abstract}
Abstrak
Artikel ini merupakan hasil penelitian terkait masalah-masalah yang dihadapi guru dalam meningkatkan keaktifan siswa dalam suatu pembelajaran. Penelitian ini bertujuan untuk mencari tahu faktor-faktor yang membuat siswa kurang aktif dalam pembelajaran. Melalui metode penelitian kualitatif yang bersifat studi pustaka (library research) yang menggunakan buku-buku dan literatur-literatur lainnya sebagai objek yang utama. Hasil dari penelitian ini menunjukkan bahwa ada beberapa faktor yang membuat siswa kurang aktif dalam suatu pembelajaran, yaitu: 1) kompetensi yang dimiliki guru, 2) kurangnya motivasi belajar, 3) kesalahan guru.
\end{abstract}

Kata Kunci: problematika guru Matematika, meningkatkan aktivitas siswa, pembelajaran Matematika

\section{Abstract}

This article is the result of research related to the problems faced by teachers in increasing student activity in learning. This study aims to find out the factors that make students less active in learning. Through qualitative research methods that are library research which uses books and other literatures as the main object. The results of this study indicate that there are several factors that make students less active in learning, namely: 1) teacher competencies, 2) lack of motivation to learn, 3) teacher mistakes.

\section{PENDAHULUAN}

Pendidikan adalah usaha sadar dan terencana untuk mewujudkan suasana belajar dan proses pembelajaran agar peserta didik secara aktif mengembangkan potensi dirinya untuk memiliki kekuatan spiritual kagamaan, pengendalian diri, kepribadian, kecerdasan, akhlak mulia, serta keterampilan yang diperlukan dirinya, masyarakat bangsa dan negara menurut 
UU. RI. No. 20 Tahun 2003 tentang Sistem Pendidikan Nasional. Pendidikan dalam kehidupan sehari-hari merupakan bagian dari kehidupan masyarakat dimana proses pendidikan telah ada sejak awal adanya manusia di muka bumi. Dalam pendidikan terdapat proses belajar yang dialami setiap individu yang berkecimpung di dalamnya, proses belajar ini sebagai akibat dari adanya perasaan ingin tahu dari setiap manusia. ${ }^{1}$ Dalam melakukan proses pendidikan dan pembelajaran, memerlukan seorang pendidik yang membimbing, mengajari, serta mendidik para siswa yang dikenal dengan sebutan guru.

Menurut Undang-undang No.14 Tahun 2005, Guru adalah tenaga pendidik profesional di bidangnya yang memiliki tugas utama dalam mendidik, mengajar, membimbing, memberi arahan, memberi pelatihan, memberi penilaian, dan mengadakan evaluasi kepada peserta didik yang menempuh pendidikannya sejak usia dini melalui jalur formal pemerintahan berupa Sekolah Dasar hingga Sekolah Menengah.

Guru adalah pendidik, yang menjadi tokoh, panuta bagi peserta didik, dan lingkungannya. Oleh karena itu, guru harus memiliki standar kualitas pribadi tertentu, yang mencakup tanggung jawab, wibawa, mandiri, dan disiplin. Berkaitan dengan tanggung jawab, guru harus mengetahui, serta memahami nilai, norma moral, dan sosial, serta berusaha berperilaku dan berbuat sesuai dengan nilai dan norma tersebut. Guru juga harus bertanggung jawab terhadap segala tindakannya dalam pembelajaran di sekolah, dan dalam kehidupan bermasyarakat. $^{2}$

Setiap guru pasti memiliki sebuah permasalahan dalam menghadapi para siswanya, karena antara siswa satu dengan lainnya memiliki kepribadian yang berbeda-beda. Permasalahan atau problematika yang dihadapi oleh seorang guru bermacam-macam, mulai dari siswa kesulitan mencerna materi pelajaran yang disampaikan oleh guru hingga permasalahan yang dihadapi oleh guru pada saat proses belajar mengajar di kelas seperti keaktifan siswa, yang tidak semua siswa dapat aktif.

Pengertian dari problematika yaitu suatu permasalahan yang bersumber atau berasal dari hubungan dua faktor, sehingga menimbulkan situasi yang sangat menyulitkan dan memerlukan adanya suatu penyelesaian atau pemecahan tanpa harus menilai terlebih dahulu manakah yang lebih cepat. Berdasarkan permasalahan yang ada, penulis tertarik untuk membuat artikel yang berjudul "Problematika Guru Dalam Meningkatkan Keaktifan Siswa Di Kelas Pada Pembelajaran Matematika". Karena problematika mengenai

\footnotetext{
${ }^{1}$ Sumiati, Peranan Guru Kelas Dalam Meningkatkan Motivasi Belajar Siswa,(Makasar:Tarbawi, Jurnal Pendidikan Agama islam, Vol. 3, No. 2, 2018).

2 Isjoni, "Guru sebagai Motivator Perubahan" (Yogyakarta: Pustaka Belajar, 2009), 23.
}

Problematika guru dalam meningkatkan aktivitas siswa di kelas pada pembelajaran Matematika 
keaktifan siswa di dalam kelas sering menjadi masalah bagi para guru, sehingga ini perlu dikaji lagi mengapa siswa banyak yang tidak aktif di dalam kelas terutama pada pelajaran matematika.

\section{METODE PENELITIAN}

Metode penelitian pada dasarnya merupakan cara ilmiah untuk mendapatkan data dengan tujuan dan kegunaan tertentu. Untuk mencapai tujuan yang diperlukan dibutuhkan metode yang relevan untuk mencapai tujuan yang diinginkan (Sugiyono, 2016:1)

\section{a. Jenis penelitian}

Penelitian ini adalah penelitian kualitatif yang bersifat studi pustaka (library research yang menggunakan buku-buku dan literatur-literatur lainnya sebagai objek yang utama (Hadi, 1995:3). Studi pustaka merupakan langkah awal dalam metode pengumpulan data. Studi pustaka merupakan metode pengumpulan data yang diarahkan kepada pencarian data dan informasi melalui dokumen-dokumen, baik dokumen tertulis, foto-foto, gambar, maupun dokumen elektronik yang dapat mendukung dalam proses penulisan. "Hasil penelitian juga akan semakin kredibel apabila didukung foto-foto atau karya tulis akademik dan seni yang telah ada".(Sugiyono, $2005: 83$ ).

\section{b. Sumber data}

Sebagai penelitian studi pustaka, maka sumber data yang digunakan dalam penelitian ada dua macam yaitu sumber primer dan sumber sekunder, yang akan di paparkan sebagai berikut:

1. Sumber primer, yaitu sumber utama atau referensi yang menjadi acuan bagi penelitian. Dalam penelitian ini sumber primer/utama yang digunakan adalah jurnaljurnal tentang pendidikan, guru dan yang mencakup keaktifan siswa.

2. Sumber sekunder yaitu sumber atau referensi-referensi pendukung dan pelengkap bagi sumber primer. Dalam penelitian ini sumber sekunder yang digunakan adalah buku yang berjudul Etika Profes Keguruan karya Imron Fauzi.

\section{c. Metode pengumpulan Data}

Metode secara umum diartikan sebagai proses, cara, atau prosedur yang digunakan untuk memecahkan suatu masalah. Metode yang digunakan untuk mengumpulkan data dalam penelitian ini adalah studi pustaka. Dimana data-data yang diperoleh dalam penelitian ini bersumber dari literasi-literasi maupun buku-buku. Data yang disajikan 
adalah data yang berbentuk kata yang memerlukan pengolahan supaya ringkas dan sistematis (Muhadjir, 1998: 29).

\section{HASIL DAN PEMBAHASAN}

Sebagai seorang guru yang memiliki tugas mendidik siswa, maka memiliki peran yang penting dalam proses pembelajaran. Kualitas hubungan antara guru dan peserta didik menentukan keberhasilan proses pembelajaran yang efektif. Mengingat begitu pentingnya peranan hubungan antara guru dan peserta didik dalam menentukan keberhasilan pembelajaran, maka guru dituntut untuk mampu menciptakan hubungan yang positif. Guru dituntut untuk menciptakan suasana yang kondusif agar peserta didik bersedia terlibat sepenuhnya pada kegiatan pembelajaran. ${ }^{3}$

Peran seorang guru sangat signifikan dalam proses belajar mengajar. Peran guru dalam proses belajar mengajar meliputi banyak hal seperti pengajar, manajer kelas, supervisor, motivator, konsuler, eksplanator. Yang akan dikemukakan disini adalah peran yang dianggap paling dominan, yaitu sebagai berikut:

1. Konsevator (pemelihara) sistem nilai yang merupakan sumber norma kedewasaan, inovator (pengembang) sistem nilai ilm u pengetahuan;

2. Trasnmitor (penerus) sistem-sistem nilai kepada peserta didik;

3. Transformator (penerjemah) sistem-sistem nilai melalui penjelmaan dalam pribadinya dan perilakunya, dalam proses interaksi dengan sasaran didik;

4. Organisator (penyelenggara) terciptanya proses edukatif yang dapat dipertanggung jawabkan, baik secara formal (kepada pihak yang mengangkat dan menugaskannya) ataupun secara moral (kepada sasaran didik, serta Tuhan yang menciptakannya). ${ }^{4}$

Guru dalam menjalankan tugasnya sebagai pendidik harus memiliki standard kompetensi yang mencakup kompetensi pedagogik, kepribadian, sosial, dan profesional. Kompetensi guru adalah kemampuan seorang guru dalam penguasaan pengetahuan, keterampilan, mnilai dan sikap dalam menjalankan tugasnya dengan baik apabila memiliki kemampuan yang sesuai dengan bidang keahliannya. Guru dalam mengajar harus memiliki kompetensi mengajar agar mampu menciptakan lingkungan belajar yang efektif dan

\footnotetext{
${ }^{3}$ Imron Fauzi, Etika Profesi Keguruan (Jember: IAIN Press, 2017), 81.

${ }^{4}$ Sumiati, Peranan Guru Kelas Dalam Meningkatkan Motivasi Belajar Siswa,(Makasar:Tarbawi, Jurnal Pendidikan Agama islam, Vol. 3, No. 2, 2018).
} 
menyenangkan. Kompetensi guru yang profesional akan menjadikan mutu pendidikan di Indonesia lebih baik lagi. ${ }^{5}$

Menjadi seorang guru tentu bukan hal yang mudah, banyak problem/masalah yang dihadapi, terutama pada saat pembelajaran di dalam kelas, salah satunya yaitu mengenai keaktifan siswa di kelas. Agar problematika tersebut bisa diatasi oleh guru, maka guru harus memiliki kompetensi.

Kompetensi merupakan perpaduan antara pengetahuan, kemampuan, dan penerapan dalam melaksanakan tugas di lapangan kerja. Menurut Undang-Undang Republik Indonesia Nomor 14 Tahun 2005 Tentang Guru dan Dosen menyatakan bahwa kompetensi adalah seperangkat pengetahuan, keterampilan, dan perilaku yang harus dimiliki, dihayati, dan dikuasai oleh guru atau dosen dalam melaksanakan tugas keprofesionalan. Menurut Finch \& Crunkilton, (1992: 220) Menyatakan "Kompetencies are those taks, skills, attitudes, values, and appreciation thet are deemed critical to successful employment". Pernyataan tersebut mengandung makna bahwa kompetensi meliputi tugas, keterampilan, sikap, nilai, apresiasi yang diberikan dalam rangka keberhasilan hidup/penghasilan hidup.

Selain kompetensi yang harus dimiliki seorang guru, guru juga harus dapat memotivasi peserta didik agar semangat belajar. Seperti yang telah di jelaskan dalam jurnal Tarbawi volume 3 No.2 bahwa motivasi sangat diperlukan untuk terciptanya proses pembelajaran di kelas secara efektif. ${ }^{6}$ Motivasi memiliki peranan yang sangat penting dalam pembelajaran baik dalam proses maupun pencapaian hasil. Siswa yang memiliki motivasi tinggi, pada umumnya mampu meraih keberhasilan dalam proses maupun output pembelajaran. Oleh karena itu, seorang guru dituntut mampu mengkreasikan berbagai cara agar motivasi siswa dapat muncul dan berkembang dengan baik.

Keatifan siswa di dalam kelas menurun terjadi karena ada hal-hal yang membuat siswa kurang bersemangat seperti kurang sukanya dalam mata pelajaran itu dan motivasi siswa yang kurang. Karena setiap individu dari diri siswa memiliki kondisi internal yang turut berperan dalam aktivitasnya sehari-hari. Salah satu dari kondisi internal tersebut adalah "motivasi". Siswa yang memiliki motivasi kuat, akan mempunyai banyak energi untuk belajar dan itu dpaat membangun keaktifan dari diri siswa tersebut. Keberhasilan belajar siswa bisa ditentukan dari motivasi belajar yang dimilikinya. Siswa yang memiliki motivasi

\footnotetext{
${ }^{5}$ Umu Syaida, Bambang Suyadi \& Hety Mustika Ani,Pengaruh Kompetensi Guru Terhadap Hasil Belajar Ekonomi di SMA Negeri Rambipuji Tahun Ajaran 2017/1018,(Jurnal Pendidikan Ekonomi Vol. 12 No. 2, 2018), 186.

${ }^{6}$ Sumiati, Peranan Guru Kelas Dalam Meningkatkan Motivasi Belajar Siswa,(Makasar:Tarbawi, Jurnal Pendidikan Agama islam, Vol. 3, No. 2, 2018).
} 
belajar tinggi cenderung prestasinya akan tinggi pula, namun sebaliknya, siswa yang motivasinya rendah, maka akan rendah pula prestasi belajarnya. ${ }^{7}$ Seorang siswa yang memiliki inteligensia yang tinggi, bisa saja gagal karena kekurangan motivasi. Prestasi belajar akan optimal kalau memiliki motivasi yang tepat (Sardiman, 2016).

Motivasi yang diberikan guru diharapkan bisa menjadi semangat untuk siswa yang malas dalam hal belajar baik dilingkungan sekolah maupun rumah. Pengertian motivasi sendiri yaitu dorongan yang timbul pada diri seseorang, secara sadar atau tidak sadar untuk melakukan suatu tindakan dengan tujuan tertentu.

Muhammad Asrori motivasi ialah usaha-usaha yang dapat menyebabkan seseorang atau kelompok orang tertentu tergerak melakukan sesuatu karena ingin mencapai tujuan yang ingin dicapai (Muhammad Asrori, 2007:183). Selanjutnya menurut Abraham Maslow motivasi adalah sesuatu yang bersifat konstan (tetap) tidak pernah berakhir, berfluktasi dan bersifat kompleks dan hal itu kebanyakan merupakan karakteristik universal pada setiap organisasi. Lebih lanjut Atksion mendefinisikan motivasi sebagai suatu tendensi seseorang untuk berbuat yang meningkat guna menghasilkan satu hasil atau lebih pengaruh. ${ }^{8}$

Hal ini berkaitan dengan metode yang digunakan guru dalam proses pembelajaran, diharapkan di dalam proses pembelajaran seorang guru tidak terpaku pada satu metode saja, tetapi harus menggunakan metode yang bervariasi agar tidak membosankan, dan menarik perhatian peserta didik khususnya di dalam meningkatkan motivasi siswa dalam pembelajaran. ${ }^{9}$

Menurut Haryanto menyebutkan bahwa terdapat enam hal yang mempengaruhi keaktifan siswa di kelas yaitu: siswa, guru, materi, tempat, waktu, dan fasilitas. Peran guru dibutuhkan dalam proses aktifitas di sebuah kelas, karena guru merupakan penanggung jawab semua bentuk kegiatan pembelajaran di kelas, aktifitas di kelas bisa diskenario guru sesuai dengan tujuan pembelajaran yang diinginkan. Keaktifan siswa membuat pembelajaran berjalan sesuai dengan perencanaan pembelajaran yang sudah disusun oleh guru, bentuk aktifitas siswa dapat berbentuk aktifitas pada dirinya sendiri atau aktifitas dalam suatu kelompok. ${ }^{10}$

\footnotetext{
${ }^{7}$ Yosi Intan Pandini Gunawan, Pengaruh Motivasi Belajar terhadap Keaktifan Siswa dalam Mewujudkan Prestasi Belajara Siswa, (Garut : Khazanah Akademia, Vol. 02, No. 01, 2018), hlm. 78

${ }^{8}$ Purwa Atmaja Prawira, Psikologi Pendidikan dalam Perspektif Baru, (Jogjakarta: Ar- Ruzz Media, 2014), hal.320.

${ }^{9}$ Sumiati, Peranan Guru Kelas Dalam Meningkatkan Motivasi Belajar Siswa,(Makasar:Tarbawi, Jurnal Pendidikan Agama islam, Vol. 3, No. 2, 2018).

${ }^{10}$ Ulfaun Nikmah, "PERAN GURU DALAM MENINGKATKAN KEAKTIFAN SISWA MELALUI MEDIA PEMBELAJARAN PADA MATA PELAJARAN IPA DI SDN 1 KARANGAN BALONG PONOROGO", (Ponorogo : IAIN Ponorogo, 2018), 3.
}

Problematika guru dalam meningkatkan aktivitas siswa di kelas pada pembelajaran Matematika 
Problem mengenai keaktifan siswa yaitu siswa kurang aktif bertanya kepada guru terkait pembelajaran yang belum dimengerti dan belum optimalnya keaktifan siswa mengeluarkan pendapat ketika menjawab pertanyaan guru saat pembelajaran berlangsung, maka peran guru untuk meningkatkan keaktifan siswa terutama ketika proses kegiatan belajar berlangsung sangatlah penting. ${ }^{11}$ Dalam mata pelajaran matematika keaktifan siswa sangatlah diperlukan, karena supaya siswa tidak salah dalam melakukan perhitungan, menempatkan rumus dan apakah siswa itu memahami materi tersebut atau tidak.

Siswa dapat dilihat keaktifannya di dalam kelas saat mengikuti pembelajaran dapat dilihat dari empat indikator yaitu, pertama siswa mengajukan pertanyaan kepada guru tentang materi yang dijelaskan, kedua bila guru memberikan pertanyaan maka siswa tersebut dengan cepat menjawab pertanyaanya, ketiga siswa mengerjakan soal-soal latihan yang telah diberikan oleh guru, yang keempat bila siswa yang aktif biasanya akan mengerjakan soal di depan kelas walaupun dia tidak di tunjuk oleh gurunya.

Dari keempat indikator itu tidak semua siswa bisa memenuhinya, karena pribadi setiap siswa berbeda-beda. Ada yang dengan berani maju ke depan untuk menjelaskan atau mengerjakan soal, ada yang dengan cepat menjawab pertanyaan dan untuk siswa yang memiliki pemikiran kritis akan bertanya mengenai materi yang memang telah dijelaskan atau yang telah dipelajari dengan mandiri.

Problematika dalam artikel ini mengenai keaktian siswa di dalam mata pelajaran matematika. Matematika berdasakan artinya merupakan cabang pengetahuan dari ilmu eksak, dan juga matematika sebagai induk/ratu dari segala macam pengetahuan, seperti kimia, fisika dan ekonomi. Matematika biasanya dikenal dengan ilmu hitung, tetapi matematika juga diperoleh dengan cara bernalar. Sehingga memerlukan konsentrasi, pemahaman serta kecermatan yang tinggi bila mengerjakan soal matematika. Maka dalam pembelajaran matematika siswa dituntut supaya mendengarkan dengan baik dan siswa dituntut untuk aktif bertanya karena jika dalam pembelajaran ini tidak memahami jika pada saat penghitungan atau penalaran salah maka hasil dan cara pengerjaannya juga berbeda.

Matematika merupakan salah satu pelajaran yang dapat mengembangkan kemampuan berpikir siswa, memiliki struktur dan keterkaitan antar konsep yang kuat sehingga membuat siswa mesti terampil berpikir secara rasional dan logis (Depdiknas, 2003). Siswa mempelajari matematika mulai dari tingkat sekolah dasar hingga tingkat sekolah menengah yang menjadi dasar untuk melanjutkan ke jenjang perguruan tinggi. Siswa tidak akan berhasil mempelajari

\footnotetext{
${ }^{11}$ Yosi Intan Pandini Gunawan, Pengaruh Motivasi Belajar terhadap Keaktifan Siswa dalam Mewujudkan Prestasi Belajara Siswa, (Garut : Khazanah Akademia, Vol. 02, No. 01, 2018), 79.
} 
matematika tingkat sekolah menengah, apabila konsep matematika di sekolah dasar tidak dipahami dengan baik. Begitu juga dengan di perguruan tinggi, siswa akan kesulitan mempelajari konsep matematika yang tingkat tinggi apabila konsep matematika di tingkat sekolah menengah saja tidak mengerti. ${ }^{12}$ Oleh karena itu, keaktifan siswa sangat diperlukan dalam mempelajari pelajaran matematika.

Faktor-faktor yang menyebabkan siswa tidak aktif di dalam kelas dapat juga disebabkan dari kesalahan seorang guru saat mengajar. Kesalahan-kesalahan seorang guru yaitu, pertama tidak adanya persiapan dari guru ketika akan melaksanakan pembelajaran. Kedua, guru menunggu peserta didik berperilaku negative, peserta didik akan berkembang secara optimal melalui perhatian guru yang positif, sebaliknya perhatian yang negatif akan menghambat perkembangan peserta didik. Tidak sedikit guru yang sering mengabaikan perkembangan kepribadian peserta didik, serta lupa memberikan pujian kepada mereka yang berbuat baik dan tidak membuat masalah. Biasanya guru baru memberikan perhatian kepada peserta didik ketika sudah ribut, tidak memperhatikan penjelasan guru dan hal negative lainnya.

Ketiga, mengabaikan keragaman peserta didik, dalam hal ini peserta didik memiliki emosi yang sangat bervariasi, dan sering memperlihatkan sejumlah perilaku yang tampak aneh. Setiap peserta didik memiliki perbedaan yang unik, mereka memiliki kekuatan, kelemahan, minat dan perhatian yang berbeda-beda. Keempat, memperlakukan peserta didik secara tidak adil, pada saat guru menebarkan pertanyaan, pembimbingan, pelayanan pinjammeminjam alat dan sarana pendidikan, dan paling sering dilakukan guru adalah dalam pemberian nilai. Proses pembelajaran yang di dalamnya terkandung suatu unsur diskriminatif sesungguhnya tidak efektif lagi. Kesalahan yang sering dilakukan oleh guru terutama dalam memberikan penilaian, di mana seharusnya guru melakukan secara adil karena nilai merupakan cermin dari perilaku peserta didik sebagai wujud penghargaan sesuai dengan usahanya selama proses pembelajaran. ${ }^{13}$

Dari keempat faktor tersebut yang membuat siswa lainnya tidak dapat aktif yaitu adanya diskriminatif. Dimana dalam hal ini terdapat beberapa guru yang lebih cenderung kepada anak yang dianggap paling pintar di kelas yang diakuinya selalu aktif baik bertanya maupun menjawab dan mengerjakan soal-soal latihan. Karena adanya sifat diskriminatif yang membuat guru buta akan siswa lainnya.

\footnotetext{
${ }^{12}$ Harry Dwi Putra, dkk,"Kemampuan Mengidentifikasi Kecukupan Data pada Masalah SPLDV dan SelfEfficacy Siswa MTs",Jurnal Nasional Pendidikan Matematika, Vol. 2 No. 1 (2018), 49.

${ }^{13}$ Imron Fauzi, Etika Profesi Keguruan (Jember: IAIN Press, 2017), 253-259.
}

Problematika guru dalam meningkatkan aktivitas siswa di kelas pada pembelajaran Matematika 


\section{SIMPULAN DAN SARAN}

Beberapa kesimpulan dari problematika guru dalam meningkatkan keaktifan siswa dalam kelas pada pembelajaran matematika adalah:

1. Kompetensi, dimana guru harus memiliki kompetensi agar dapat menggunakan metode pembelajaran yang sesuai dengan kondisi yang sedang terjadi. Baik dari kondisi siswa, kelas, sekolah maupun lingkungan sekitar. Sehingga dalam praktinya tidak terjadi kesenjangan antara gaya belajar siswa dengan metode yang digunakan guru. Dan juga diharapkan di dalam proses pembelajaran seorang guru tidak terpaku pada satu metode saja, tetapi harus menggunakan metode yang bervariasi agar tidak membosankan.

2. Motivasi, guru juga harus dapat memotivasi siswa agar siswa memiliki minat belajar. Karena untuk memunculkan minat belajar siswa diperlukan peran guru yang dapat memotivasi belajarnya. Dengan siswa memiliki minat belajar, maka seorang siswa akan aktif dalam suatu pembelajaran.

3. Kesalahan guru, guru yang mengabaikan siswanya. Yang kadang guru juga lupa untuk memberi pujian/reward kepada siswa yang berprestasi. Padahal dengan pujian/reward siswa akan menjadi lebih bersemangat dalam mengikuti pelajaran tersebut. Kesalahan lain yang guru lakukan ialah membeda-bedakan antara murid yang pintar dengan murid yang kurang pintar. Terlihat pada saat guru menebarkan pertanyaan, pembimbingan, pelayanan pinjam-meminjam alat dan sarana pendidikan, dan paling sering dilakukan guru adalah dalam pemberian nilai.

Berdasarkan Kesimpulan yang dikemukaan, maka beberapa saran yang perlu dipertimbangkan yaitu guru harus memiliki kompetensi yang sesuai dengan bidangnya. Artinya, guru harus menguasai materi sebelum mengajar. Selain itu, guru juga harus mempertimbangkan metode pengajaran yang digunakan, agar dalam prosesnya siswa dapat menerima materi yang disampaikan guru.

Untuk menumbuhkan motivasi siswa, hendaknya guru memberikan semacam reward kepada siswa yang telah berhasil menyelesaikan tugasnya dengan baik. Dengan begitu siswa akan merasa bersemangat dan berusaha mendapatkan reward tersebut dengan giat belajar dan juga aktif dalam pembelajaran matematika.

\section{DAFTAR PUSTAKA}

\section{Books:}

Fauzi, Imron. 2017. Etika Profesi Keguruan. Jember: IAIN Press.

Isjoni. 2009. Guru sebagai Motivator Perubahan. Yogyakarta: Pustaka Belajar. 
Nikmah, Ulfatun. 2018. Peran Guru Dalam Meningkatkan Keaktifan Siswa Melalui Media Pembelajaran Pada Mata Pelajaran Ipa Di Sdn 1 Karangan Balong Ponorogo. Ponorogo : IAIN Ponorogo.

Prawira, Purwa Atmaja. 2014. Psikologi Pendidikan dalam Perspektif Baru. Jogjakarta:

Ar- Ruzz Media.

\section{Online journal:}

Gunawan, Yosi Intan Pandini. "Pengaruh Motivasi Belajar terhadap Keaktifan Siswa dalam Mewujudkan Prestasi Belajara Siswa Garut”. Khazanah Akademia, Vol. 02, No. 01. (2018).

Putra, Harry Dwi. Dkk."Kemampuan Mengidentifikasi Kecukupan Data pada Masalah SPLDV dan Self-Efficacy Siswa MTs”. Jurnal Nasional Pendidikan Matematika, Vol. 2 No. 1 (2018).

Sumiati. "Peranan Guru Kelas Dalam Meningkatkan Motivasi Belajar Siswa". Jurnal Pendidikan Agama Islam, Volume 3 No.2 (2018).

Syaida, Umi. Suyadi, Bambang. Ani, Hety Mustika Ani. "Pengaruh Kompetensi Guru Terhadap Hasil Belajar Ekonomi di SMA Negeri Rambipuji Tahun Ajaran 2017/1018”.Jurnal Pendidikan Ekonom, Vol. 12 No. 2 (2018). 